\author{
Piotr Oleśniewicz \\ Mariusz Soltysik ** \\ University School of Physical Education in Wrocław \\ Julita Markiewicz-Patkowska*** \\ Wrocław School of Banking in Wrocław \\ Justyna Cieplik ${ }^{* * * *}$ \\ University School of Physical Education in Wrocław
}

\title{
SCHOOL TOURISM AS PART OF PHYSICAL EDUCATION \\ IN THE LIGHT OF TOURIST ACTIVITIES DECLARED BY HIGH SCHOOL STUDENTS IN WROCLAW, POLAND
}

\begin{abstract}
The objective of the study is to recognize the expectations of high school students with regard to various forms of school tourism, and with the school tourism teacher's personality. The study was performed during the second semester of 2009-2010 school year among 250 students of selected high schools in Wrocław, Poland. The method of the diagnostic poll and the questionnaire technique have been applied. Also, a discussion of literature in the field is provided. The results indicate that high schools students are interested in participating in tourism classes over the course of physical education classes, and the interest in tourism is similar for boys and girls. Students share a similar personal profile of a school tourism teacher. They appreciate the sense of responsibility, as well as educational and interpersonal skills. The personal example of a physical education teacher can play a vital role in initiating interest and passion for tourism.
\end{abstract}

Keywords: school tourism, high school, optional classes, teacher's personal profile

\footnotetext{
* E-mail address: piotr.olesniewicz@awf.wroc.pl.

** E-Mail address: mariusz.soltysik@awf.wroc.pl.

****E-Mail address: julita.markiewicz-patkowska@wsb.wroclaw.pl.

**** E-Mail address: justyna.cieplik@awf.wroc.pl.
} 


\section{Introduction}

Annual surveys conducted by the Tourism Institute for the Tourism Department of the Ministry of Sport and Tourism are aimed at specifying the features of the Polish children and youth tourist activity. The research has been carried out with a representative statistic sample of Polish citizens aged 15-19 and children under 14 who belonged into the respondents' household. It referred to short- and long-term domestic and foreign departures. The results published in the reports of the Tourism Institute ${ }^{1}$ indicate that the participation of children under 14 in domestic tourist trips in 2005-2009 remained steady (42-44\%). The lowest rate of participation was observed in 2006 (42\%), while the highest in 2008 (46\%). The participation of the youth aged 15-19 in the same period amounted to $61-68 \%$. The lowest level was observed in $2005(61 \%)$, whereas the highest in 2008 (68\%).

According to the declarations, in 23\% of the respondents aged 15-19 in 2009 the lack of tourist activities was a result of conditioned needs. The youth stated that they felt neither willingness nor need to take trips. Only $6 \%$ mentioned organizational reasons (they had nowhere to go or nobody to help organize recreation). In the analysed period, the youth's interests changed; in 2005-2006, the main purpose of trips was tourist and sightseeing activity, while in 2007-2009 visiting relatives and friends. Typically, tourist purposes were manifested more often by boys and the older youth groups. The most frequently chosen forms were individual trips (a drop from 83\% in 2008 to 68\% in 2009), but also journeys organized within parents' workplace or schools (an increase from $17 \%$ in 2008 to $32.1 \%$ in 2009). Schools organized most summer camps lasting more than 5 days for approximately $51 \%$ of children. In 2009 , tourist trips organized by travel agencies and specialized entities were on the increase (in 2008, 17\% of children took part in them and in $2009-21 \%$ ). Predictably, the form of trips will develop

J. Łaciak, Aktywność turystyczna dzieci i młodzieży w 2009 roku - raport, http://dms. msport.gov.pl/app/document/file. 
dynamically. ${ }^{2}$ The research conducted fragmentarily in smaller communities shows a similar tendency. ${ }^{3}$

The objective of the study has been to recognize the expectations of high school students with regard to various forms of school tourism. It has also been investigated whether students who enter and conclude the fourth stage of education differ in their interest in tourist activity over the course of compulsory physical education classes as well as whether their expectations associated with the school tourism teacher's personality are significantly diverse. The following research questions have been formulated:

1. Do first- and third-year students differ in terms of their willingness to participate in tourist activity?

2. Are first-year students significantly different from third-year students with regard to the preferred characteristics of a tourism teacher?

3. Does the choice of tourist classes and desirable characteristics of a tourism teacher depend on the respondents' gender?

The study was performed during the second term of 2009-2010 school year

2 J. Morawska, Dokąd zmierza turystyka młodzieżowa?, "Wiadomości Turystyczne”, 2008, No. 2, p. 12.

3 T. Fąk, Turystyka $w$ szkolnych programach wychowania $w$ opinii nauczycieli, in: Wychowanie dla turystyki: wspomaganie uczestnictwa dzieci i mtodzieży $w$ turystyce, eds. R. Gałecki, A. Gotwot-Jeziorska, W. Ruszniak, Polish Tourist Association, Warszawa, 2000, pp. 31-42; B. Kaczor, Uczestnictwo młodzieży szkolnej w turystyce kwalifikowanej (na przykładzie młodzieży szkół Poznania), in: Turystyka aktywna-turystyka kwalifikowana, eds. T. Łobożewicz, R. Kogut, Nasz Kraj, Warszawa, 1999, pp. 109-114; Z. Lubowicz, Turystyka dzieci i młodzieży szkót ponadpodstawowych w 1995 roku, "Problemy Turystyki" 1996, No. 1-4, pp. 105-110; B. Maj, Turystyka młodzieżowa w środowisku wielkomiejskim - rozmiary i formy uczestnictwa, Zeszyty Naukowe Wyższej Szkoły Gospodarki w Bydgoszczy No. 3 (2), 2005, pp. 201-217; M. Napierała, Turystyka w oczach młodzieży, Zeszyty Naukowe Wyższej Szkoły Gospodarki w Bydgoszczy, No. 1, 2004, pp. 267-274; K. Prusik, M. Bochenek, K. Görner, K. Prusik, Aktywność turystyczna a edukacja dzieci i młodzieży szkolnej z regionu południowego Podlasia, "Rocznik Naukowy AWFiS w Gdańsku” 2006, No. 16, pp. 143-152; P. Różycki, Aktywność turystyczna młodzieży polskiej w świetle dotychczasowych badań, "Folia Turistica" No. 9, 2000, pp. 89-96; M. Sołtysik, Sposoby spędzania czasu wolnego przez młodzież szkolna Wrocławia w okresach weekendowych, in: Wybrane zagadnienia turystyki, ed. U. Szubert-Zarzeczny, Wydawnictwo WSZ Edukacja, Wrocław 1999, pp. 95-114; P. Różycki, Miejsce turystyki w sposobie zagospodarowania czasu wolnego młodzieży szkót ponadpodstawowych Krakowa, "Folia Turistica" 2001, No. 10, pp. 85-89; A. Wartecka, Aktywność turystyczna młodzieży w świetle badań, "Roczniki Naukowe AWF w Poznaniu" 2001, No. 50, pp. 139-153; J. Wyrzykowski, J. Marak, K. Klimentowski, M. Sołtysik, Czas wolny mieszkańców Wrocławia i jego wykorzystanie na rekreację ruchowa i turystyke, in: Turystyka w badaniach naukowych: prace ekonomiczne, eds. A. Nowakowska, M. Przydział, WSIiZ, Rzeszów 2006, pp. 619-636. 
among 250 students of selected high schools in Wrocław from all city districts. The study for first- and third-year students was carried out in secondary and profiled secondary schools, as well as secondary technical schools supervised by the Wrocław municipality in which students of the University School of Physical Education in Wrocław, Poland, conducted their apprenticeship. It was performed in 21 high schools (36.8\%). The random sample was chosen on the basis of systematic sampling. ${ }^{4}$ In the schools in which students were surveyed their quantity and gender proportions were taken into account. Unfortunately, since the research was voluntary, some third-year students refused to participate in it; besides, not all the questionnaires were filled in correctly. Therefore, the statistical analysis has been based on 102 complete questionnaires (60 female and 42 male) of first-year students and 149 questionnaires (62 female and 87 male) of third-year students. Overall, 122 female and 129 male students have been surveyed.

While gathering data, the method of a diagnostic poll and the questionnaire technique ${ }^{5}$ were applied with HGK/PO-2009/10-U questionnaire constructed by the authors.

The research was performed by trained second-year students of the University School of Physical Education in Wrocław specializing in physical education during their pedagogic apprenticeship at schools. After they had been granted the permission for conducting of the research from the head teacher, they informed students that the research was anonymous and voluntary and acquainted students with the objective of the study.

The students were informed that, according to the regulation of the Ministry of National Education and Sport, physical education might be conducted in two forms: as regular lesson or as optional classes. Both systems are compulsory yet optional classes create the opportunity to choose their form. The students were asked which optional classes they would like to choose and when.

4 Ch. Frankfurt-Nachmias, D. Nachmias, Metody badawcze w naukach społecznych, Zysk i S-ka, Poznań 2001.

5 T. Pilch, T. Bauman, Zasady badań pedagogicznych, Żak, Warszawa 2010. 


\section{Students' preferences concerning the time and type of optional physical education classes}

The students prefer sports classes (Figure 1), appointed by nearly $40 \%$ of the respondents. The other options are preferred by a similar percentage of the students and more than $20 \%$ of them would like to participate in tourism classes.

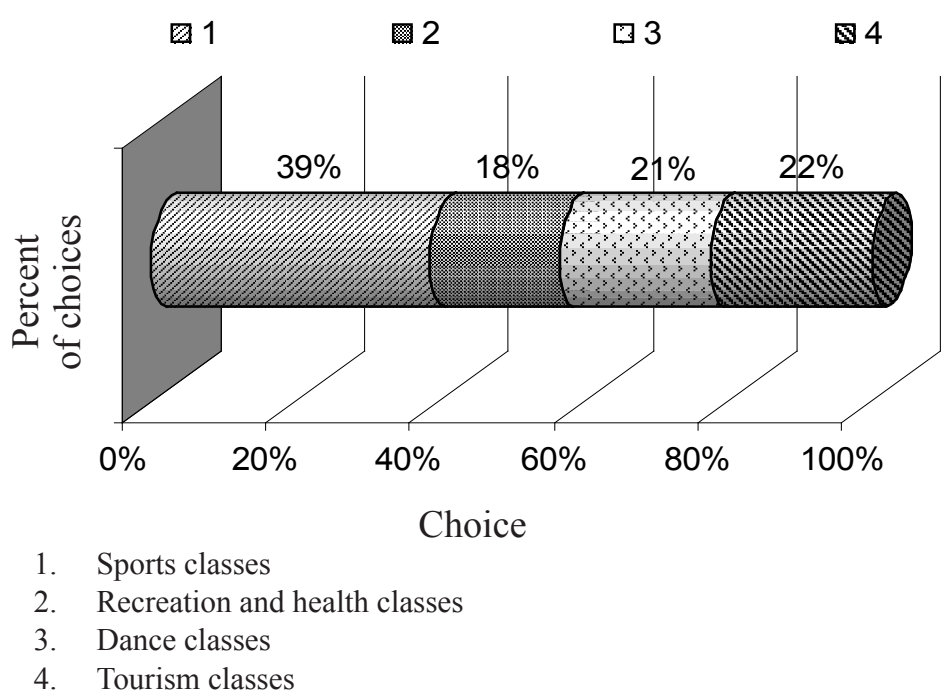

Fig. 1. Preferences of all the students concerning the kind of optional physical education classes

Source: own study.

The respondents were also enquired as regards their preferred duration of chosen classes. The results are depicted in Figure 2. 


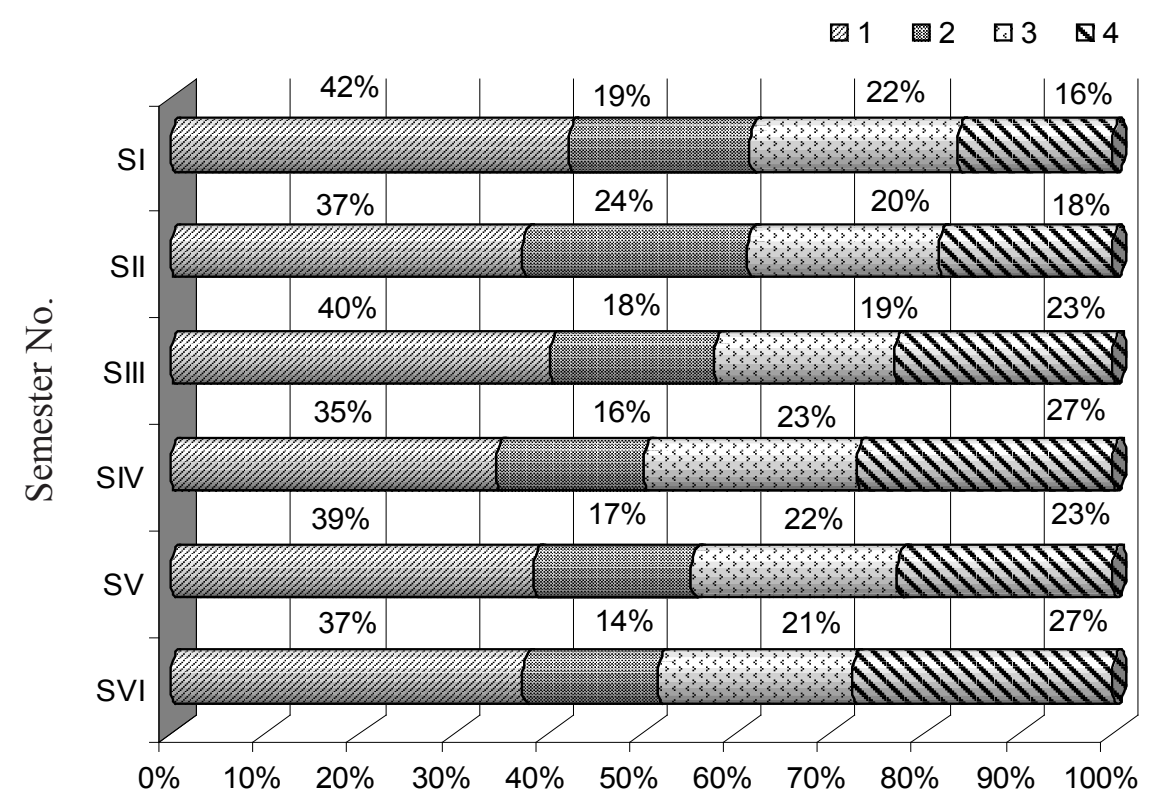

Choice

1. Sports classes

2. Recreation and health classes

3. Dance classes

4. Tourism classes

Fig. 2. Preferences of the students concerning the kind and duration of optional physical education classes

Source: own study.

The percentage of the surveyed students willing to participate in sports classes does not depend substantially on the classes duration. The smallest number of students are willing to participate in them for 4 term (35\%). The highest percentage of the students wish to attend them for only 1 term (42\%) but the percentages of those willing to attend sports classes over 2, 3 and 5 terms are similar (37-39\%). The biggest differences in the students' declarations can be observed with respect to tourism classes. The mere $16 \%$ of the respondents declare the readiness to participate in the classes for 1 semester, while in a longer period (3-6 terms), the figure increases to $23-27 \%$ of all the students. Recreation and health classes are preferred in the short duration (1 term) and in the case of dance classes, the percentage of the students ready to choose them remains steady for 1,2 and 6 terms. 
First-year students favour sports and dance classes regardless their duration (Figure 3). Recreation and health classes prove to be the least popular among the students, with the declining tendency for longer durations. On the contrary, the proportion of first-year students preferring tourist activity is increasing for durations of between 3 and 6 semesters.

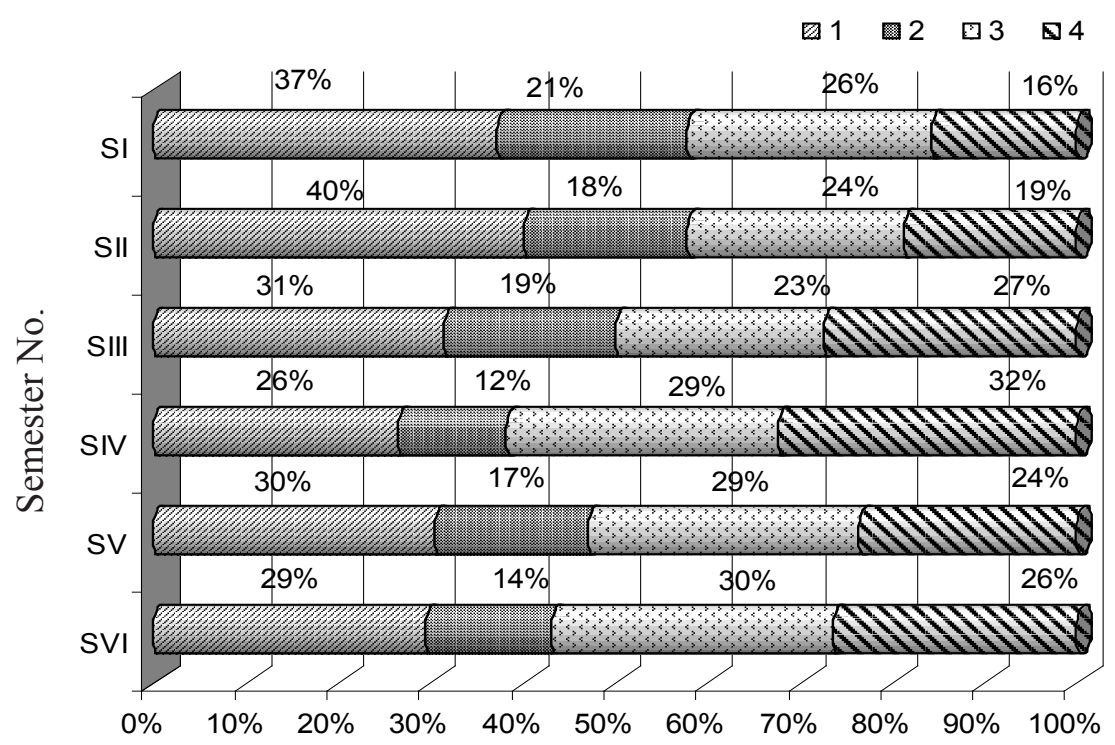

Choice

1. Sports classes

2. Recreation and health classes

3. Dance classes

4. Tourism classes

Fig. 3. Preferences of the first-year students concerning the kind and duration of optional physical education classes

Source: own study.

Nearly half of the third-year students declare their willingness to participate in sports classes (Fig. 4). The remaining percentage chooses recreation and health or dance classes in the short duration of 1-2 semesters, but they prefer tourist activity for the duration of $4-5$ terms. 


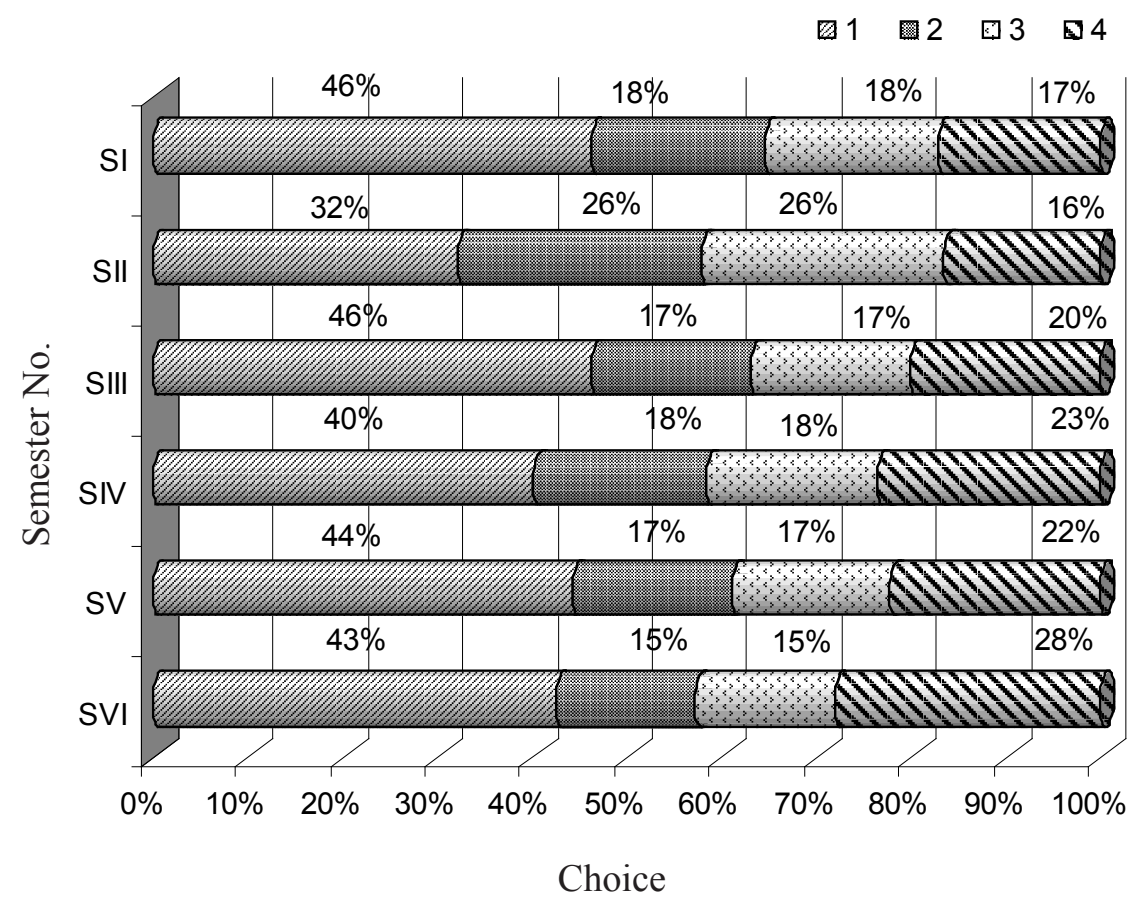

1. Sports classes

2. Recreation and health classes

3. Dance classes

4. Tourism classes

Fig. 4. Preferences of the third-year students concerning the kind and duration of optional physical education classes

Source: own study.

Female first-year students explicitly favour long-term dance (Figure 5) and also tourism classes. 


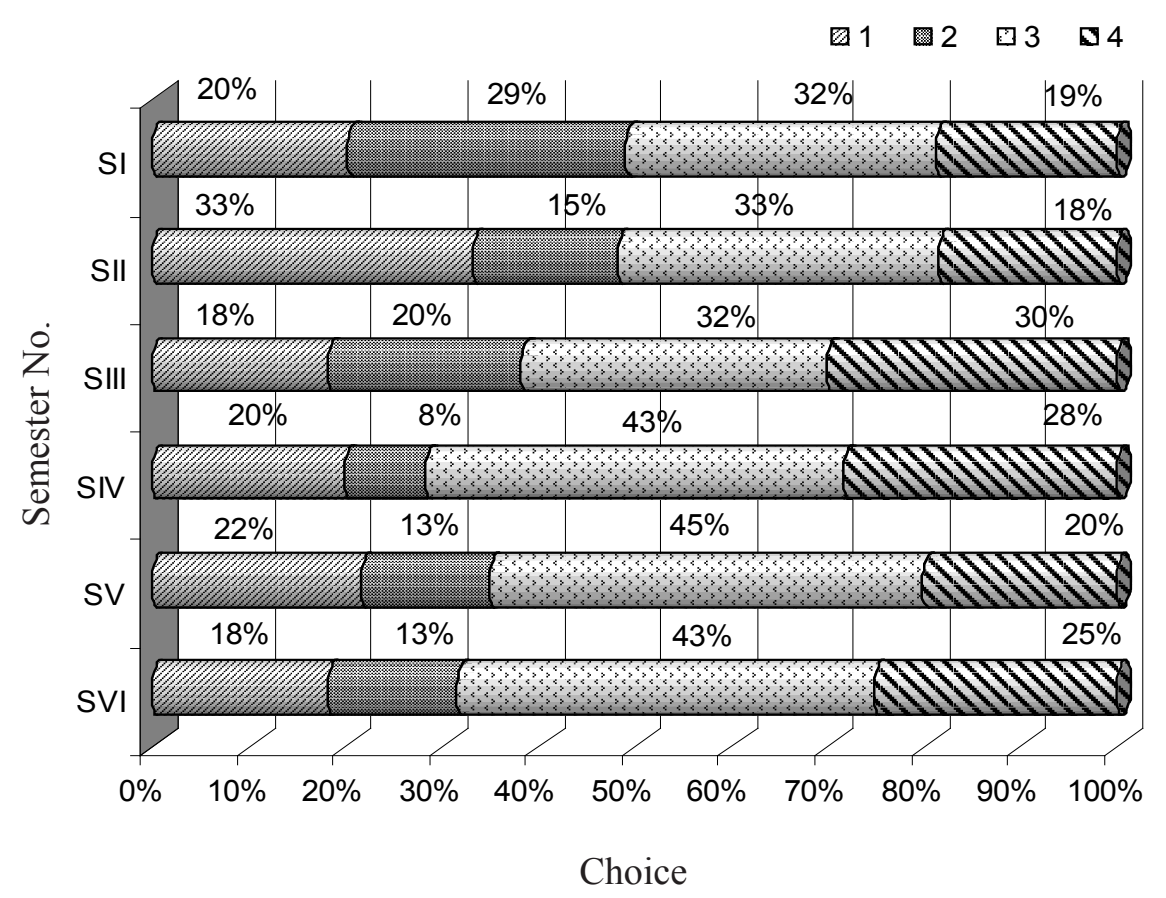

1. Sports classes

2. Recreation and health classes

3. Dance classes

4. Tourism classes

Fig. 5. Preferences of the first-year female students concerning the kind and duration of optional physical education classes

Source: own study.

Male first-year students (Figure 6) select sports classes for their physical education classes, particularly in the short duration (1 term). With regard to the longer periods (4-6 terms), the number of students willing to take part in tourism classes is rising. 


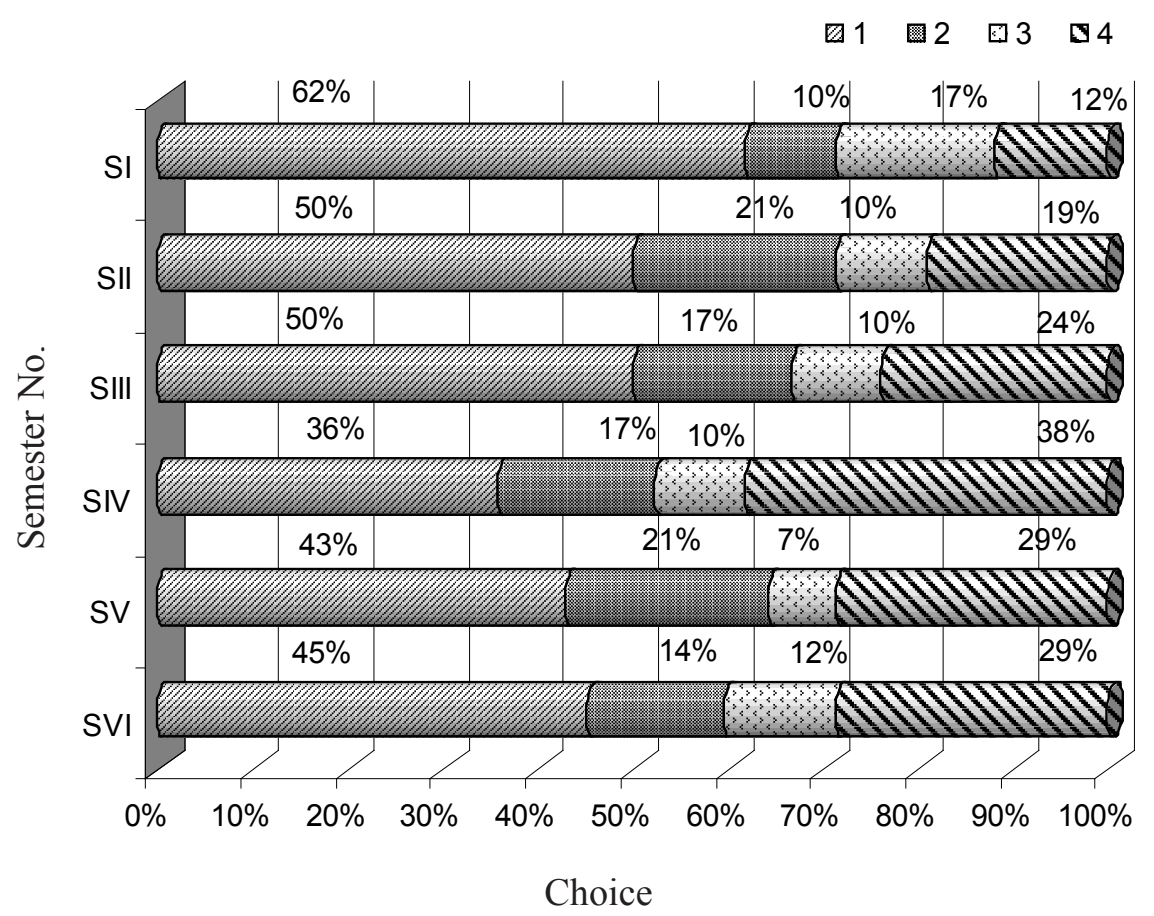

1. Sports classes

2. Recreation and health classes

3. Dance classes

4. Tourism classes

Fig. 6. Preferences of the first-year male students concerning the kind and duration of optional physical education classes

Source: own study.

The structures of choices among first-year students by genders proved to be significantly different.

The same percentage of female third-year students (Figure 7) choose sport, dance and tourism classes for longer durations (5-6 terms). The biggest proportion of girls would like to attend dance classes over 1 term. 


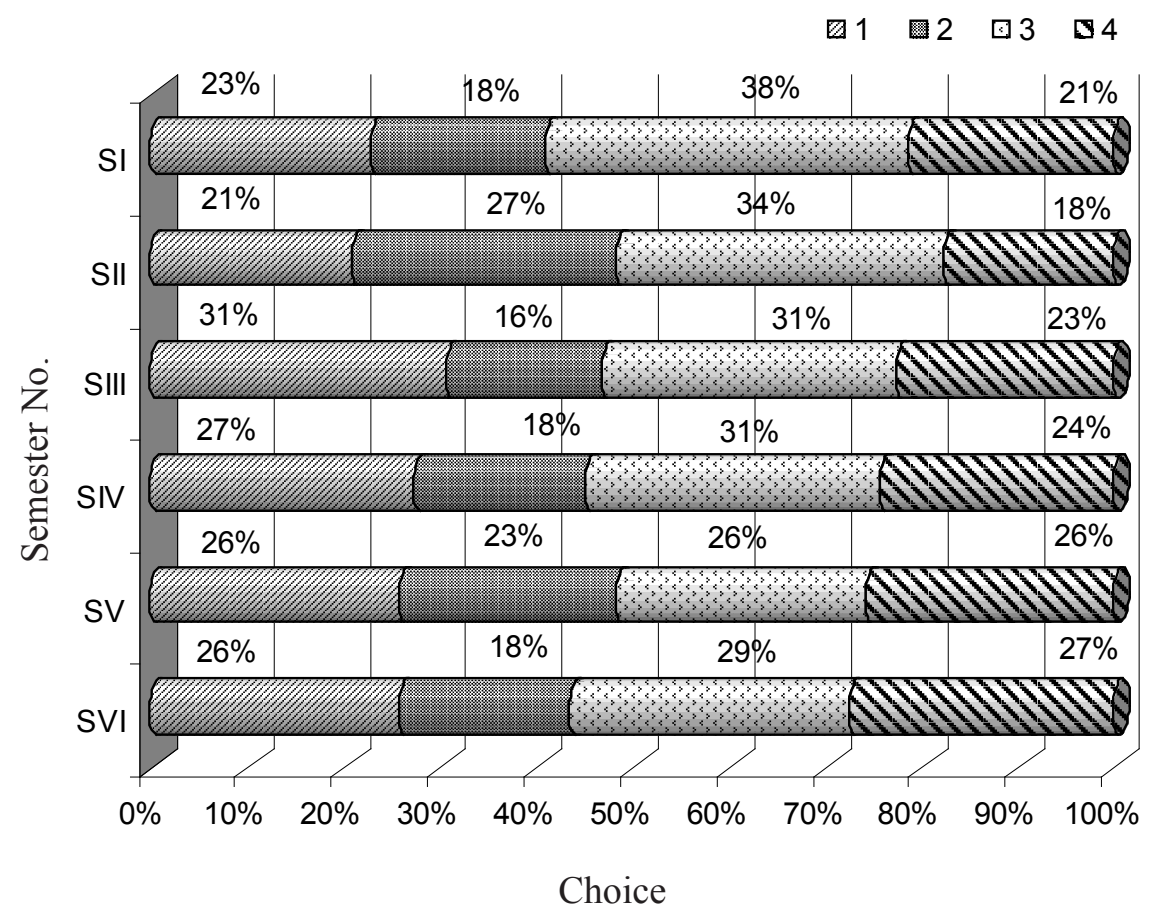

1. Sports classes

2. Recreation and health classes

3. Dance classes

4. Tourism classes

Fig. 7. Preferences of the third-year female students concerning the kind and duration of optional physical education classes

Source: own study.

Male third-year students prefer sports classes as the form of physical education (Figure 8). For the short duration, they also select recreation and health classes, whereas for the long duration - tourist activity. Only a modest percentage is interested in dance classes.

The structures of choices among third-year students by genders proved to be significantly different. 


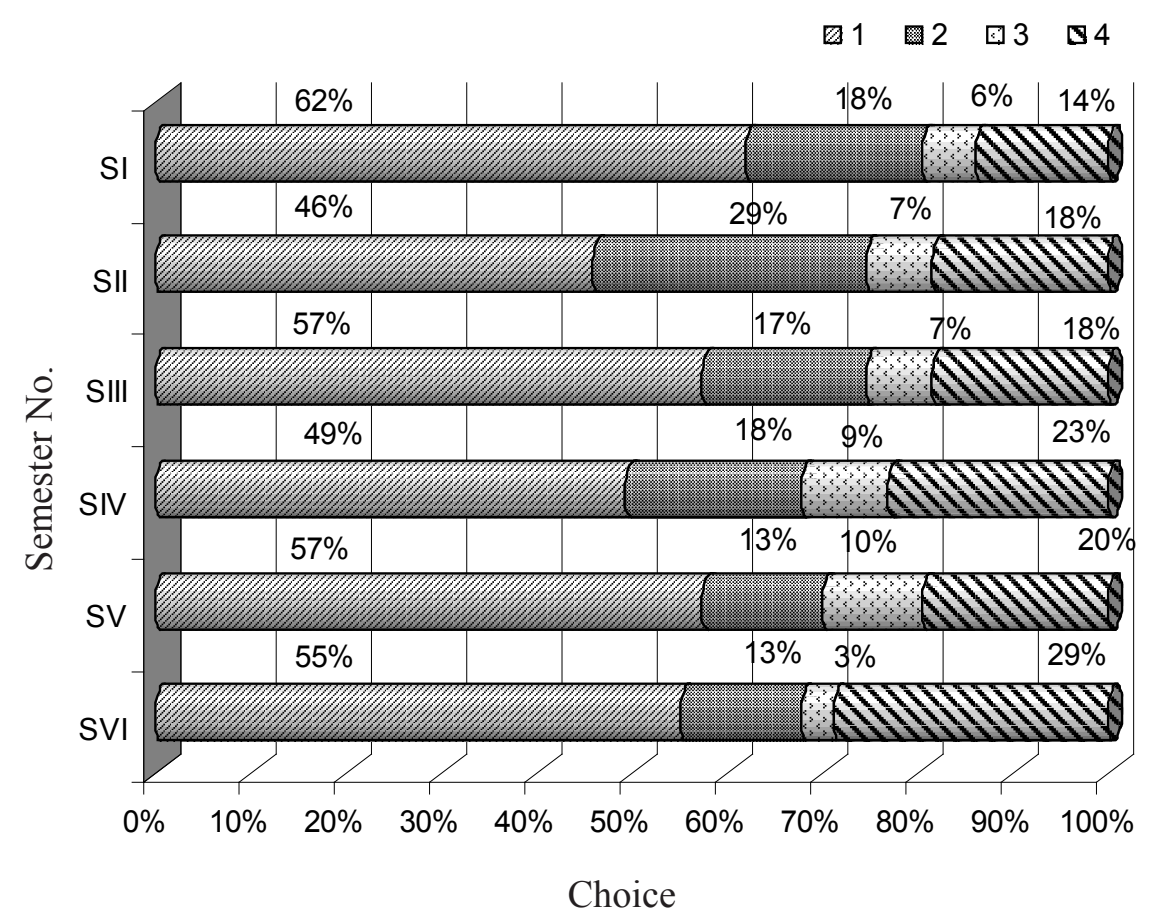

1. Sports classes

2. Recreation and health classes

3. Dance classes

4. Tourism classes

Fig. 8. Preferences of the third-year male students concerning the kind and duration of optional physical education classes

Source: own study.

\section{Authority of a school tourism teacher}

What reinforces and what weakens the authority of a school tourism teacher, according to the students? In search for an answer to the question, the researchers asked students to appoint the most desirable and expected personal features of a model school trips and walking tours teachers. The students were requested to rank 30 positive and 20 negative features from the most to the least desirable ones. 
Positive features (PF) (30): warm-hearted, friendly, kind, understanding, responsible, cheerful - with sense of humour, able to present knowledge in an attractive manner, perfect in action and professional, establishing contacts with youth easily, patient, impartial, with individual approach to young people, considerate, tactful, initiating, diligent in his commitments, intelligent, fit, just, caring of his outward appearance, knowledgeable about the regulations concerning the safety of trips, able to give first aid, co-operative, experienced in trips organization, imaginative, sensitive to moral values, resourceful, sensible, energetic, caring.

Negative features (NF) (20): quarrelsome, with little initiative, absentminded, intolerant, conceited, neglecting youth, malicious, with tendency to drink alcohol, bossy, unreliable, brutal, unpunctual, egoistic, capricious, arrogant, choosing the easy way, mendacious, unhelpful, cold, and quick-tempered.

In the ranking, a positive quality ranked 1 st obtained 30 points, while a feature ranked 30th -1 point; negative features, accordingly, were given between 20 points and 1 point. The ranking reflecting opinions of all the respondents representing the particular class was prepared on the basis of the median of points assigned to every feature. Subsequently, the medians of features chosen by boys and girls were compared. The results are presented in figures 9-12.

Ten most important personal features of a model school tourism teacher appointed by both first- and third-year students (Figures 9 and 10) include: responsible, cheerful, warm-hearted, friendly, understanding, able to present knowledge in an attractive manner, kind, establishing contacts with youth easily, patient and perfect in action (first-year students) or impartial (third-year students). The least significant features for first class students are: energetic, experienced in trips organization, and knowledgeable about the regulations concerning the safety of trips. Third-year students selected: knowledgeable about the regulations concerning the safety of trips, caring of his outward appearance, and sensitive to moral values. 


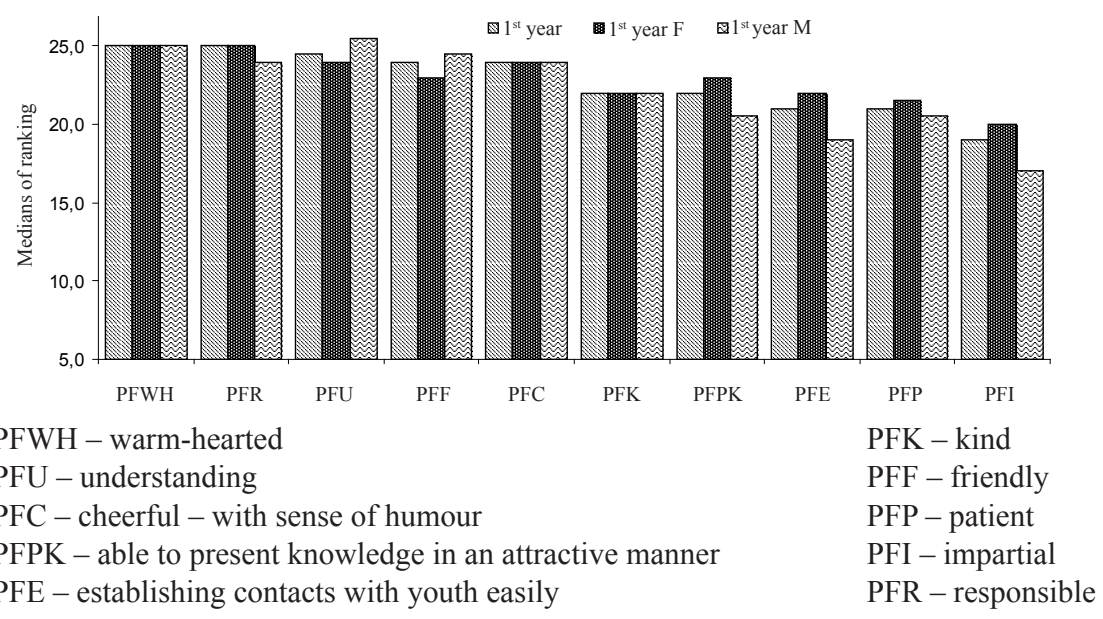

Fig. 9. Ranking of top ten positive features of a school tourism teacher appointed by all first-year students in comparison with first-year female and male choices

Source: own study.

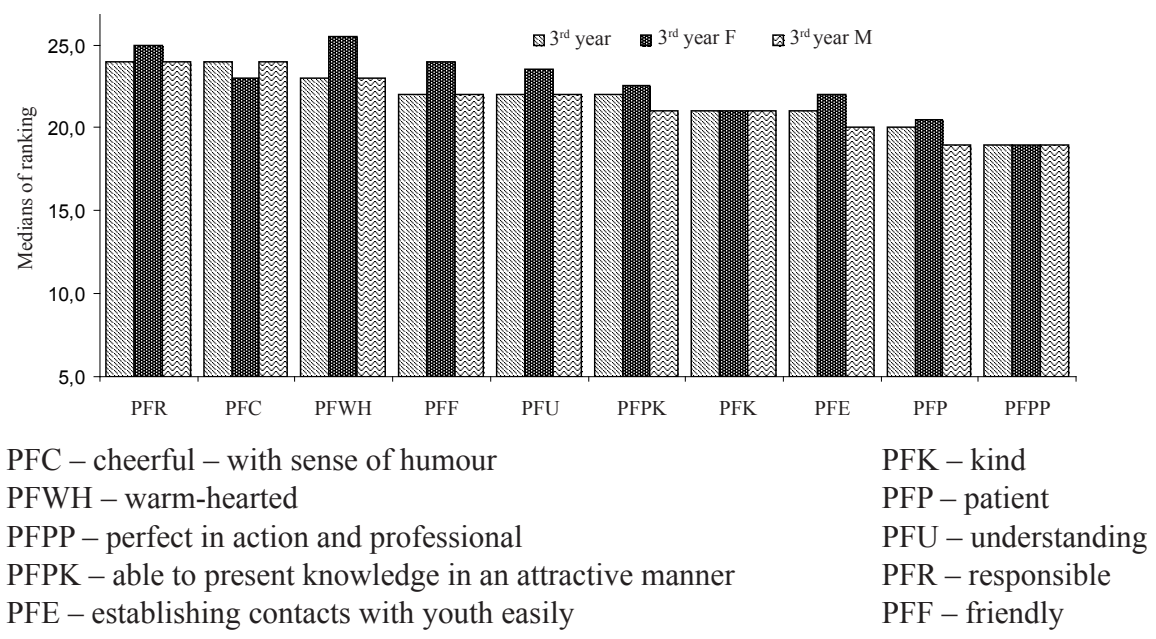

Fig. 10. Ranking of top ten positive features of a school tourism teacher appointed by all third-year students in comparison with third-year female and male choices

Source: own study. 
Undesirable, negative personal features appointed commonly by firstand third-year students (Figures 11 and 12) include: absent-minded, conceited, bossy, unpunctual, quick-tempered, unreliable, capricious, with tendency to drink alcohol, arrogant. Furthermore, for first-year students - it was conceited and with little initiative; and mendacious and cold for third-year students.

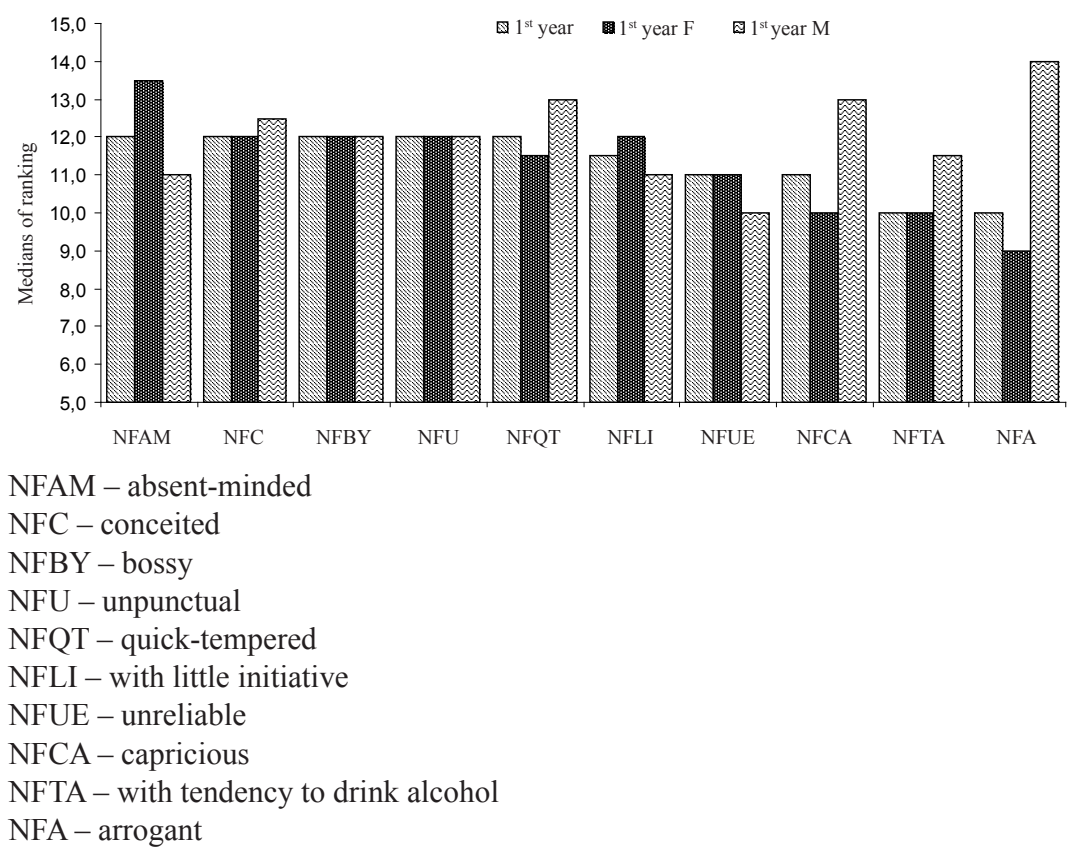

Fig. 11. Ranking of top ten negative features of a school tourism teacher appointed by all first-year students in comparison with first-year female and male choices

Source: own study. 


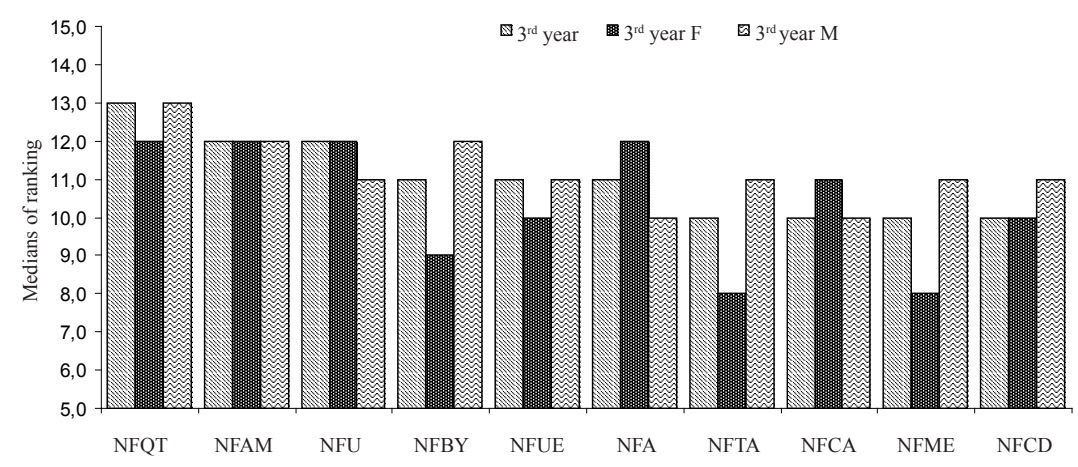

NFQT - quick-tempered

NFAM - absent-minded

NFU - unpunctual

NFBY - bossy

NFUE - unreliable

NFA - arrogant

NFTA - with tendency to drink alcohol

NFCA - capricious

NFME - mendacious

NFCD - cold

Fig. 12. Ranking of top ten negative features of a school tourism teacher appointed by all third-year students in comparison with third-year female and male choices

Source: own study.

Significant differences in the positive and negative model personal features of school tourism teachers are presented in Figures 13-16.

On the basis of the Kruskal-Wallis one-way analysis of variance, at the significance level of 0.05 , the hypothesis about the equality of intensity distribution of choosing by groups caring and experienced in trips organization should be rejected (Figure 13). 

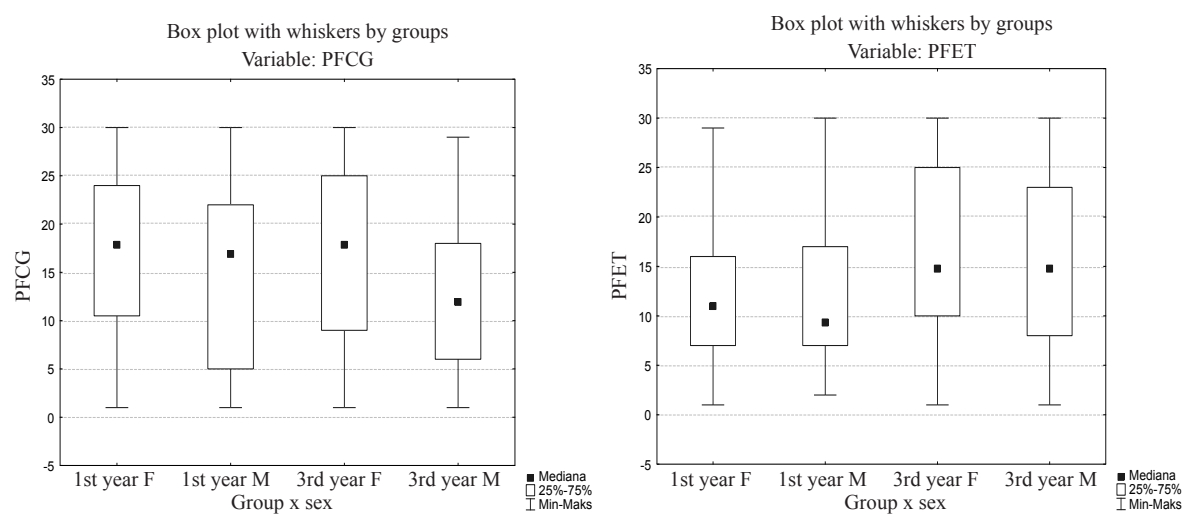

PFCG - caring

PFET - experienced in conducting trips

Fig. 13. Intensity distribution of choosing caring and experienced in trips organization features by the year and gender of the respondents

Source: own study.

A typical result of the caring feature appointed by third-year male students (3rd year M) is significantly different from the results for first- and third-year female students (1st year F and 3rd year F). Both the median and the smallest results of a typical range of variability are lower. The relationship indicates that a teacher's protectiveness is less important for high school boys (third-year) than for girls from the same group. Moreover, third-year students (3rd year F and 3rd year $\mathrm{M}$ ) value more experience in trips organization than first-year students (1st year $\mathrm{F}$ and 1 st year $\mathrm{M}$ ).

On the basis of the Kruskal-Wallis one-way analysis of variance, at the significance level of 0.05 , the hypothesis about the equality of intensity distribution of choosing by groups resourceful and with individual approach should be rejected (Figure 14). 

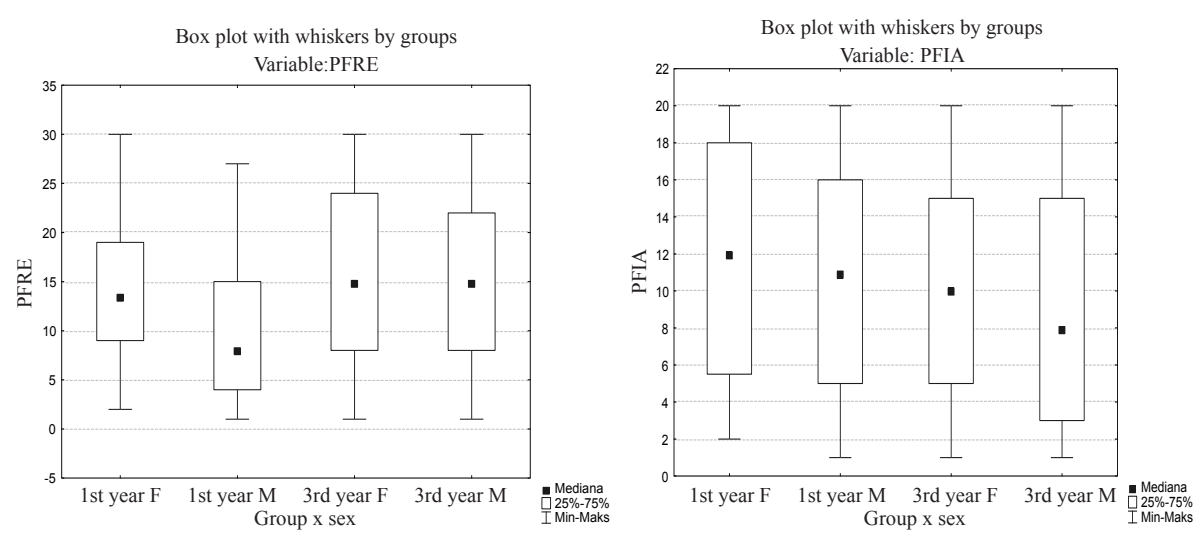

PFRE - resourceful

PFIA - with individual approach

Fig. 14. Intensity distribution of choosing resourceful and with individual approach features by the year and gender of the respondents

Source: own study.

A typical result of the resourceful feature appointed by first-year male students (1st year M) is significantly lower than the results for third-year students (3rd year F and 3rd year M). It might be assumed that the teacher's resourcefulness is appreciated by older students regardless of their gender, whereas it is not that significant for younger boys. The feature with individual approach significantly differentiates first-year female students (1st year F) and third-year male students (3rd year M). Younger girls expect an individual approach to their problems but boys seem to be more independent from their teacher.

On the basis of the Kruskal-Wallis one-way analysis of variance, at the significance level of 0.05 , the hypothesis about the equality of intensity distribution of choosing by groups with tendency to drink alcohol and bossy should be rejected (Figure 15). 

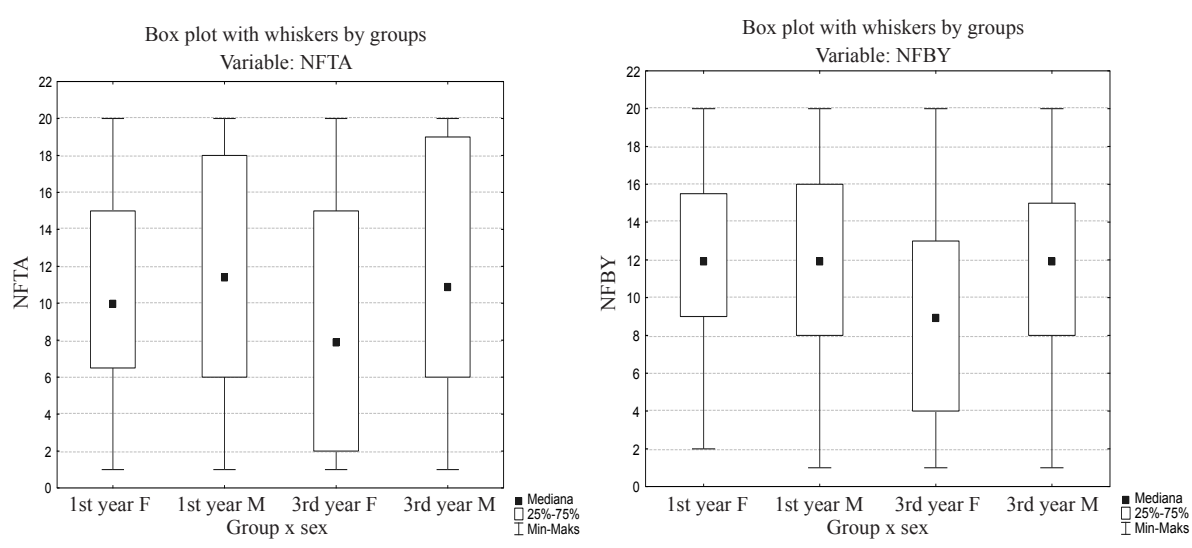

NFTA - with tendency to drink alcohol NFBY - bossy

Fig. 15. Intensity distribution of choosing with tendency to drink alcohol and bossy features by the year and gender of the respondents

Source: own study.

The first feature choice is significantly different among the third-year students (3rd year F and 3rd year M). Boys (3rd year M) evaluated such a teacher's tendency more strictly than girls (3rd year F) who appear to be more tolerant for such addiction. Girls differ with regard to their evaluation of the bossy feature. Younger students (1st year F) are definitely more emphatic in their rejection of such an attitude than older ones (3rd year F).

On the basis of the Kruskal-Wallis one-way analysis of variance, at the significance level of 0.05 , the hypothesis about the equality of intensity distribution of choosing by groups brutal and mendacious should be rejected (Figure 16). 

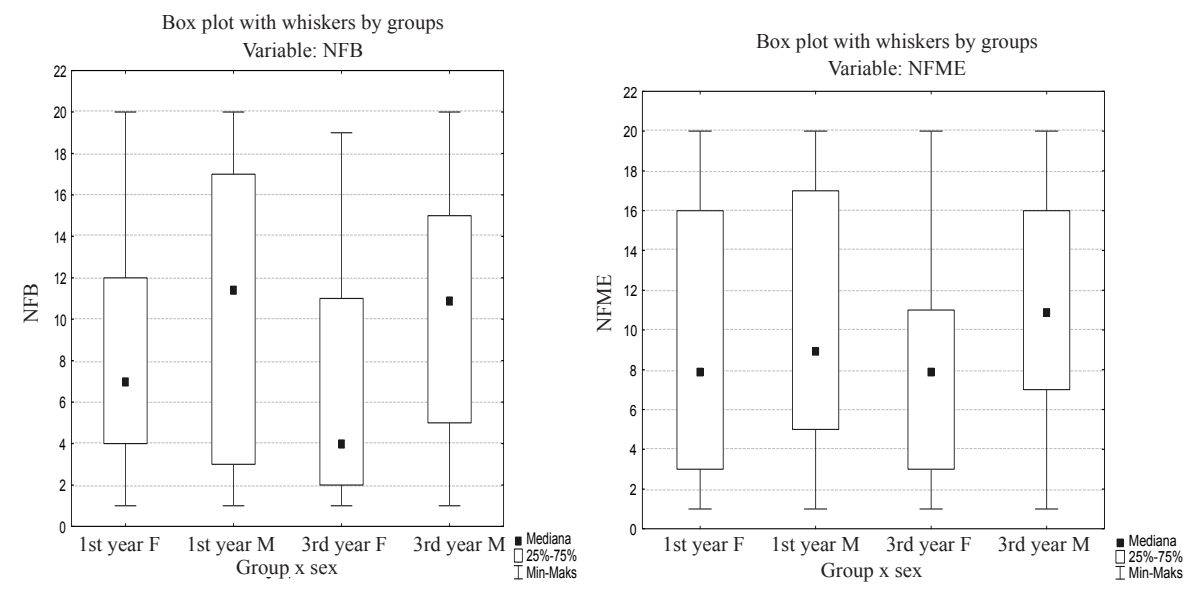

NFB - brutal

NFME - mendacious

Fig. 16. Intensity distribution of choosing brutal and mendacious features by the year and gender of the respondents

Source: own study.

Older girls (3rd year F) differ considerably in their evaluation of the brutal feature from boys (1st year M and 3rd year M). This attitude is far more negative for them than for boys. Older girls (3rd year F) also differ significantly from their peers in their view concerning the mendacious feature. They are more indulgent for a teacher with such a tendency than their male friends (3rd year M).

\section{Discussion concerning tourism forms}

The results of the research concerning youth tourism in big-city communities are convergent. The study among randomly selected high school youth aged 17 in Bydgoszcz (307 people) has showed that $17 \%$ of them declare interest in tourism and its weekend forms would be willingly chosen by more than $21 \%$. ${ }^{6}$ $12 \%$ of the analysed group do not reflect such needs and $10 \%$ gave no specific answer. $34 \%$ of the respondents declare their wish to participate in tourist trips more frequently. The preferred forms of tourism include family and friends

$6 \quad$ B. Maj, Turystyka młodzieżowa... 
visitations but over $40 \%$ of the students, regardless of the type of school, would like to choose a trip to the mountains, over the water or to another city. More than $50 \%$ of youth select trips in the companion of their peers.

The research conducted by Napierała ${ }^{7}$ among high school youth aged 15-18 in Bydgoszcz has brought more optimistic results. $75 \%$ of girls and $85 \%$ of boys prefer walking mountain tours and cycling tourism as the manner of spending their leisure time. $65 \%$ of them would favour school trips with their peers.

The secondary school youth in Cracow (884 randomly selected students of diverse schools) declare taking part in tourist activities (43.5\%). ${ }^{8}$ They are chosen nearly twice more frequently by high school students and more often by girls, mainly during summer holidays in the mountains, at the seaside, on the lakeside or abroad.

The research on leisure time activities of Wrocław youth ${ }^{9}$ has embraced primary school and secondary school youth aged 14-20 (512 students). The outcomes indicate that the ludic and social style plays predominant role in young people's behaviour, with the dominance of receptive activities (watching TV, listening to the radio, book and press reading, computer games etc.). Participation in active recreation or tourism is not very attractive for the youth but more than $40 \%$ of them have no concepts of how to diversify their leisure time activities. However, in Wyrzykowski's research, ${ }^{10}$ almost $80 \%$ of high school youth and $63 \%$ of junior high school students declare their willingness to devote more time to recreation and tourism.

The research among secondary school youth in Poznań has revealed a similar tendency. ${ }^{11}$ The interest in tourism (walking, cycling and mountain) is manifested by $81 \%$ of the respondents, with other possibilities of spending leisure time proposed. At the same time, only $3 \%$ appoint the school as a tourism organizer, while individual tourism is preferred by $43 \%$ of the students.

Prusik et al. ${ }^{12}$ have conducted a research among primary, junior high and high school pupils and students (562 people) from the south of Podlasie. $73.6 \%$ of youth

\footnotetext{
7 M. Napierała, Turystyka w oczach młodzieży...

$8 \quad$ P. Różycki, Miejsce turystyki...

9 M. Sołtysik, Sposoby spędzania czasu wolnego...

10 J. Wyrzykowski, J. Marak, K. Klimentowski, M. Sołtysik, Czas wolny...

11 B. Kaczor, Uczestnictwo młodzieży...

12 K. Prusik, M. Bochenek, K. Görner, K. Prusik, Aktywność turystyczna...
} 
participate in coach trips, $71.3 \%$ are involved in cycling tourism, with rather modest school contribution to these figures $(21.1 \%$ have taken part in events organized by schools once a year, $27.6 \%$ once a term, and $15.8 \%$ once a month).

A research has also been carried out in primary schools of the BielskoBiała district (137 pupils). A specialized educational programme "Tourism in my region" has been introduced.

Wartecka's research ${ }^{13}$ among the youth of Great Poland has showed that between 1987 and 1994 the percentage of young people who did not participate in tourist trips increased (from $6 \%$ to $12 \%$ ) and the proportion of those who took part in them declined (from $94 \%$ to $88 \%$ ).

An all-Polish research on the tourist activity of youth has been conducted as well. Różycki ${ }^{14}$, in the course of his 30 -year studies, observed the rise by $4.4 \%$ annually. In 1994 , more than $88 \%$ of the youth were involved in active tourism (mainly in secondary schools), with higher proportion of the youth from towns and cities, mostly in the companionship of peers (62\%). Trips organized by the school accounted for $35 \%$ of all trips.

Lubowicz, ${ }^{15}$ as a result of the research conducted in 100 randomly selected schools (1600 people), has come to the conclusion that the number of departures increased from $88.1 \%$ (1994) to $90.7 \%$ in 1995 . The youth's preferences referred to precise tourist plans with $91.3 \%$ of the students, mainly trips to the seaside, to the mountains, and abroad (40\%).

It can be observed that the youth tourism constitutes a significant segment of tourist movement and has become young people's lifestyle. The youth travels to the country and abroad, in different seasons of the year, and is involved in diverse forms of tourism.

A research over randomly chosen group of 100 Wrocław profiled secondary schools students ${ }^{16}$ indicates that over $40 \%$ of the students are not interested in mountain tourism and have not once gone to the conveniently situated Karkonosze Mountains. 22\% state that they have visited the mountains once or

\footnotetext{
13 A. Wartecka, Aktywność turystyczna...

14 P. Różycki, Aktywność turystyczna...

15 Z. Lubowicz, Turystyka dzieci...

16 I. Bartusiak, A. Nowak, A. Romanowska-Tołłoczko, Edukacyjne aspekty uprawiania przez młodzież turystyki górskiej, "Pedagogika, Psihologia ta Medici - Biologiczni Problemi Fizycnogo Vihovanna i Sportu” 2009, No. 9, pp. 164-169.
} 
twice. The majority of the respondents blame schools for the situation for it does not organize trips or walking tours in the area.

\section{Discussion concerning teachers' attitude}

The teacher should not only teach but also educate. In the profession, besides knowledge and practical teaching skills, particular inborn or acquired features play a vital role. They reflect a teacher's personality, ability to make students interested in the subject, and stimulating them to achieve educational success. $66 \%$ of teachers believe that particular personality qualities are essential in their profession. ${ }^{17}$ They enable a teacher to recognize other people's emotions and react adequately as well as manage their relationships. They determine the skill of inspiring and encouraging others to development, building a team spirit, leading a group, solving problems, and communicating. The opportunity of conducting physical education at school as tourism classes creates a new perspective of introducing students to the world of physical culture. The effects of education for leisure time culture in the form of well-established tourist behaviour among young people depend on how competent physical education teachers will fulfil the role of school tourism teachers. Is school sufficiently prepared to meet the youth's expectations?

Tauber's research ${ }^{18}$ aims at discovering teachers' opinions concerning the function of school tourism. 50 teachers of each speciality (physical education, geography, history, Polish, biology, physics and English) have taken part in the study. The educational values of tourism are recognized mostly by physical education (84\%) and geography teachers (82\%). $99 \%$ of the physical education teachers notice values of qualified tourism as an excellent tool to educate a modern man in physical and moral realms. The physical education, geography and biology teachers $(82 \%)$ believe that tourism develops positive features of character (bravery, independence, interpersonal and social skills).

\footnotetext{
17 M. Sołtysik, Aktywność rekreacyjno-turystyczna a czas wolny młodzieży szkolnej Wrocławia, "Człowiek i Ruch/Human Movement" 2002, No. 2 (6), pp. 75-87.

18 E. Tauber, Turystyka a wychowanie w oczach badanych nauczycieli, in: Czas wolny, rekreacja, turystyka, hotelarstwo, żywienie (Wyniki badań naukowych), eds. W. Siwiński, R. Tauber, E. Mucha-Szajek, Wyższa Szkoła Hotelarstwa i Gastronomii, Zeszyty Naukowe Wyższej Szkoły Hotelarstwa i Gastronomii w Poznaniu, Poznań, 2003, pp. 473-476.
} 
A research among students ( 425 people) and graduates ( 275 people) of all the physical education universities in Poland ${ }^{19}$ indicates that they evaluate their preparation as sufficient but they do not feel well-prepared to plan and apply educative responsibilities. Further studies on the problem ${ }^{20}$ demonstrate that the level of preparation of physical education students is lower than tourism and recreation students. The latter are not permitted to work at schools as teachers so they cannot teach physical education in optional classes form. Therefore, introducing the term "school tourism teacher" would unambiguously indicate that the mentioned classes are not only extracurricular (with voluntary participation).

\section{Conclusion}

The principal question of the present study is related to high school students' interest in active tourism education and the personality profile of a teacher who introduces them to the world of leisure time culture values.

Approximately $30 \%$ of the respondents (first- and third-year students) are interested in participating in school tourism classes (as optional classes) rather than in the course of compulsory physical education at school. The percentage increases along with the duration of tourism classes - from $16 \%$ of the students for one term to nearly $30 \%$ for 4,5 or 6 terms. The differences in the students' declarations by genders can be observed only among first-year students. Boys favour tourism classes, whereas girls tend to prefer dance classes.

19 A. Gajdzińska, Przygotowanie do zawodu specjalisty turystyki i rekreacji, in: Czas wolny, rekreacja, turystyka, hotelarstwo, żywienie (Wyniki badań naukowych), eds. W. Siwiński, R. Tauber, E. Mucha-Szajek, Wyższa Szkoła Hotelarstwa i Gastronomii, Zeszyty Naukowe Wyższej Szkoły Hotelarstwa i Gastronomii w Poznaniu, Poznań 2003, pp. 487-493.

20 H. Guła-Kubiszewska, P. Oleśniewicz, Edukacja do kultury czasu wolnego a cechy wzorcowe animatorów turystyki szkolnej, in: Humanistyczny wymiar kultury fizycznej, ed. M. Zasada, Uniwersytet Kazimierza Wielkiego w Bydgoszczy, Monografie No. 12/10, Bydgoszcz-LwówWarszawa, Ośrodek Rekreacji, Sportu i Edukacji w Poznaniu, Poznań, 2010, pp. 40-63; H. Guła-Kubiszewska, P. Oleśniewicz, Turystyka szkolna - przygotowanie edukatorów w ocenie studentów kierunku wychowanie fizyczne oraz turystyka i rekreacja, in: Ewaluacja i innowacje w edukacji. Kompetencje i odpowiedzialność nauczyciela, ed. J. Grzesiak, Uniwersytet im. A. Mickiewicza w Poznaniu, PWSzZ w Koninie, Kalisz-Konin 2010, pp. 251-552; H. Guła-Kubiszewska, P. Oleśniewicz, Turystyka szkolna: poziom przygotowania studentów wychowania fizycznego do prowadzenia zajęć, in: Sbornik recenzovanych prispevku z mezinarodni vedecke konference 'Hotelnictvi, turismus a vzdelavani dnes a zitra', Vysoka skola hotelova, Praha 2010, pp. 80-89. 
First- and third-year students agree as to the nine key features of a model school tourism teacher. He ought to be responsible, cheerful, warm-hearted, friendly, understanding, able to present knowledge in an attractive manner, kind, establishing contacts with youth easily, and patient. The characteristic of the least importance for the students is knowledge about the regulations concerning the safety of trips.

The common undesirable personal features appointed by first- and third-year students include: absent-minded, conceited, bossy, unpunctual, quick-tempered, unreliable, capricious, with tendency to drink alcohol, and arrogant.

The students significantly differ in selecting the following personal features: caring, experienced in trips organization, resourceful, with little initiative, with tendency to drink alcohol, bossy, brutal, and mendacious. Younger girls (firstyear students) appreciate a teacher with a rich initiative in trip conducting, unlike their older school friends (third-year students). All the girls expect a teacher to be caring, unlike the older boys. All boys oppose more the teacher's tendency to drink alcohol than the third-year female students. However, they are more indulgent than the older girls for violent and brutal behaviour. The girls differ considerably in their evaluation of the bossy feature. The older ones would be more willing to tolerate it than their younger friends. A resourceful teacher is valued higher by third-year students (both boys and girls) than by younger boys. The older boys and girls (third-year students) differ with respect to their evaluation of the mendacious feature. Boys appear to be more indifferent towards it than their female friends, who require from a teacher a higher level of honesty and reliability.

Establishing the authority of a school physical education teacher in the new role will not be easy. Therefore, school tourism animators should be carefully selected, thoroughly educated, and constantly trained. ${ }^{21}$

To sum up the collected data, the following can be ascertained:

1. Students of high schools in Wrocław (the first and last year of their education) are interested in participating in tourism classes over the course of physical education classes. The willingness is manifested by approximately $30 \%$ of the respondents.

2. Students' declarations concerning the form of optional classes is differentiated by the gender of the respondents - girls choose mainly dance classes,

${ }^{21} \quad$ M. Sołtysik, Aktywność rekreacyjno-turystyczna... 
while boys select chiefly sports classes. The interest in tourism is similar for boys and girls.

3. Students share a similar personal profile of the school tourism teacher. They appreciate the sense of responsibility, as well as educational and interpersonal skills.

4. Girls and boys representing various education levels manifest differences in their evaluation of a personal profile of a model school tourism teacher with regard to the following features: caring, experienced in trips organization, resourceful, with individual approach to young people, with tendency to drink alcohol, bossy, brutal, and mendacious.

The face of school education in sightseeing and tourism, both inside and outside of school, will be formed, among others, by physical education teachers who will try to fit the new role of school tourism teacher. The personal example of a physical education teacher can play a vital role in initiating interest and passion for tourism. New, attractive perspectives are open for conducting school physical education in big cities, the perspectives of shaping genuine participants of tourist culture.

\section{References}

Bartusiak T., Nowak A., Romanowska-Tołłoczko A., Edukacyjne aspekty uprawiania przez młodzież turystyki górskiej, "Pedagogika, Psihologia ta Medici - Biologiczni Problemi Fizycnogo Vihovanna i Sportu" 2009, No. 9.

Fąk T., Turystyka $w$ szkolnych programach wychowania $w$ opinii nauczycieli, in: Wychowanie dla turystyki: wspomaganie uczestnictwa dzieci i mlodzieży w turystyce, eds. R. Gałecki, A. Gotwot-Jeziorska, W. Ruszniak, Polish Tourist Association, Warszawa 2000.

Frankfurt-Nachmias Ch., Nachmias D., Metody badawcze w naukach społecznych, Zysk i S-ka, Poznań 2001.

Gajdzińska A., Przygotowanie do zawodu specjalisty turystyki i rekreacji, in: Czas wolny, rekreacja, turystyka, hotelarstwo, żywienie (Wyniki badań naukowych), eds. W. Siwiński, R. Tauber, E. Mucha-Szajek, Zeszyty Naukowe Wyższej Szkoły Hotelarstwa i Gastronomii w Poznaniu, Wyższa Szkoła Hotelarstwa i Gastronomii, Poznań 2003.

Guła-Kubiszewska H., Oleśniewicz P., Edukacja do kultury czasu wolnego a cechy wzorcowe animatorów turystyki szkolnej, in: Humanistyczny wymiar kultury fizycznej, ed. M. Zasada, Monografie No. 12/10, Uniwersytet Kazimierza Wielkiego w Bydgoszczy Bydgoszcz-Lwów-Warszawa; Ośrodek Rekreacji, Sportu i Edukacji w Poznaniu, Poznań 2010. 
Guła-Kubiszewska H., Oleśniewicz P., Turystyka szkolna: poziom przygotowania studentów wychowania fizycznego do prowadzenia zajęć, in: Sbornik recenzovanych prispevku z mezinarodni vedecke konference 'Hotelnictvi, turismus a vzdelavani dnes a zitra', Vysoka skola hotelova, Praha 2010.

Guła-Kubiszewska H., Oleśniewicz P., Turystyka szkolna - przygotowanie edukatorów w ocenie studentów kierunku wychowanie fizyczne oraz turystyka i rekreacja, in: Ewaluacja i innowacje w edukacji. Kompetencje i odpowiedzialność nauczyciela, ed. J. Grzesiak, Uniwersytet im. A. Mickiewicza w Poznaniu, PWSzZ w Koninie, Kalisz-Konin 2010.

Kaczor B., Uczestnictwo młodzieży szkolnej w turystyce kwalifikowanej (na przykładzie młodzieży szkót Poznania), in: Turystyka aktywna-turystyka kwalifikowana, eds. T. Łobożewicz, R. Kogut, Nasz Kraj, Warszawa 1999.

Lubowicz Z., Turystyka dzieci i młodzieży szkót ponadpodstawowych w 1995 roku, "Problemy Turystyki" 1996, No. 1-4.

Łaciak J., Aktywność turystyczna dzieci i młodzieży w 2009 roku - raport, http://dms. msport.gov.pl/app/document/file.

Maj B., Turystyka młodzieżowa w środowisku wielkomiejskim - rozmiary i formy uczestnictwa,Zeszyty Naukowe Wyższej Szkoły Gospodarki w Bydgoszczy No. 3(2), Bydgoszcz 2005.

Morawska J., Dokąd zmierza turystyka młodzieżowa?, "Wiadomości Turystyczne” 2008, No. 2.

Napierała M., Turystyka w oczach młodzieży, Zeszyty Naukowe Wyższej Szkoły Gospodarki w Bydgoszczy No. 1, Bydgoszcz 2004.

Pilch T., Bauman T., Zasady badań pedagogicznych, Żak, Warszawa 2010.

Prusik K., Bochenek M., Görner K., Prusik K., Aktywność turystyczna a edukacja dzieci i młodzieży szkolnej z regionu południowego Podlasia, "Rocznik Naukowy AWFiS w Gdańsku” 2006, No. 16.

Różycki P., Aktywność turystyczna młodzieży polskiej w świetle dotychczasowych badań, "Folia Turistica" 2000, No. 9.

Różycki P., Miejsce turystyki w sposobie zagospodarowania czasu wolnego młodzieży szkót ponadpodstawowych Krakowa, "Folia Turistica" 2001, No. 10.

Sołtysik M., Aktywność rekreacyjno-turystyczna a czas wolny młodzieży szkolnej Wrocławia, „Człowiek i Ruch/Human Movement” 2002, No. 2 (6).

Sołtysik M., Sposoby spędzania czasu wolnego przez młodzież szkolna Wrocławia w okresach weekendowych, in: Wybrane zagadnienia turystyki, ed. U. Szubert-Zarzeczny, Wydawnictwo WSZ Edukacja, Wrocław 1999.

Tauber E., Turystyka a wychowanie w oczach badanych nauczycieli, in: Czas wolny, rekreacja, turystyka, hotelarstwo, żywienie (Wyniki badań naukowych), eds. W. Siwiński, R. Tauber, E. Mucha-Szajek, Zeszyty Naukowe Wyższej Szkoły Hotelarstwa i Gastronomii w Poznaniu, Wyższa Szkoła Hotelarstwa i Gastronomii, Poznań 2003.

Wartecka A., Aktywność turystyczna młodzieży w świetle badań, "Roczniki Naukowe AWF w Poznaniu" 2001, No. 50. 
Wyrzykowski J., Marak J., Klementowski K., Sołtysik M., Czas wolny mieszkańców Wroclawia i jego wykorzystanie na rekreacje ruchowa i turystyke, in: Turystyka w badaniach naukowych: prace ekonomiczne, eds. A. Nowakowska, M. Przydział, WSIiZ, Rzeszów 2006.

\section{TURYSTYKA SZKOLNA JAKO ELEMENT WYCHOWANIA FIZYCZNEGO W ŚWIETLE AKTYWNOŚCI TURYSTYCZNEJ DEKLAROWANEJ PRZEZ UCZNIÓW SZKÓŁ ŚREDNICH WROCŁAWIA}

\section{Streszczenie}

Celem badania było rozpoznanie oczekiwań uczniów szkół średnich w zakresie różnorodnych form turystyki szkolnej, a także profilu osobowościowego nauczyciela turystyki szkolnej. Badanie przeprowadzono w drugim semestrze roku szkolnego 2009/2010 wśród 250 uczniów wybranych szkół średnich na terenie Wrocławia. Zastosowano metodę sondażu diagnostycznego oraz technikę ankiety. W pracy przedstawiono też omówienie wyników innych badań dotyczących prezentowanego tematu. Wyniki wskazują, że uczniowie szkół średnich są zainteresowani uczestnictwem w zajęciach turystyki szkolnej w ramach wychowania fizycznego; chęć taką deklarują zarówno dziewczęta, jak i chłopcy. Uczniowie mają też podobne oczekiwania dotyczące profilu osobowościowego nauczyciela. Cenią poczucie odpowiedzialności, a także umiejętność przekazywania wiedzy i zdolności interpersonalne. Osobisty przykład nauczyciela wychowania fizycznego może mieć duże znaczenie w kształtowaniu zainteresowań i pasji turystycznych.

Słowa kluczowe: turystyka szkolna, szkoła średnia, zajęcia opcjonalne, profil osobowościowy nauczyciela 